\title{
ECTOPROCTAN FAUNA OF DEEPAR WETLAND OF ASSAM, INDIA
}

\author{
Girindra Kalita ${ }^{1}$ and M.M. Goswami ${ }^{2}$ \\ ${ }^{1}$ Lecturer, Guwahati College, Guwahati, Assam, India \\ ${ }^{2}$ Department of Zoology, Gauhati University, Guwahati, Assam 781014, India \\ Email: ${ }^{1}$ kkhlgu@gw1.vsnl.net; ${ }^{2}$ mrigen_goswami@rediffmail.com
}

web supplement

\begin{abstract}
Five bryozoan species were encountered during a limnological investigation in Deepar wetland, a perennial water body situated between $91^{\circ} 38^{\prime}-91^{\circ} 40^{\prime} \mathrm{E}$ \& $26^{\circ} 6^{\prime}-26^{\circ} 8^{\prime} \mathrm{N}$ near Guwahati, the capital city of Assam, India. The identified species are Hislopia lacustris moniliformis, Hyalinella punctata, Pactinatella gelatinosa, Plumatella emarginata and Fredericella sultana. Micro-structural features of the species are studied in limnological laboratory of Gauhati University. All the species are not reported earlier from this region. Some physical and chemical parameters of the wetland are also studied. As there is sporadic literature on ectoproctan species from this region, it is anticipated that the study will help in future research activities on this group of animals.

\section{KEYWORDS}

Bryozoa, Deepar wetland, Ectoprocta, microhabitat, new records, taxonomy
\end{abstract}

Reports of occurrence of Bryozoa from the freshwater resources of Assam remain unclaimed by freshwater biologists engaged in reporting plankton and nekton from the region as well as performing limnological research in its wetlands. Ectoproctan diversity in the wetlands was overlooked during all sorts of limnological reconnaissance in the wetlands of Assam probably due to its superficial periphytonic association. The freshwater Ectoproctan fauna have attracted worldwide scientific attention which can be traced to the last part of $18^{\text {th }}$ century as pioneered by Blumenbach (1780) and followed by many other workers to Plumatella are reported from Assam (Rao, 1992) and an unidentified species from Chandubi wetland (Goswami, 1985).

In the Indian context freshwater Bryozoa was first reported by Annandale (1906) and remained unattended by more than five decades thereafter. However, there has been quite a resurgence of interest among Indian workers mostly in reporting species of Bryozoa from different freshwater systems and studying their biology (Benerjee \& Motwani 1960; Bushnell \& Rao 1974, 1979; Rao, 1976; Choubey, 1984). Besides contribution of various workers in describing Indian species, the compilation of the most recent available information about Bryozoa and review of Indian species of freshwater Ectoprocta by Rao (1992) is a splendid contribution as on today's status of the group.

The present study is a part of limnological reconnaissance of enmeshed fauna in Deepar wetland of Assam, in which the bryozoan diversity is considered as a bait for biologists interested to study the enmeshed invertebrate fauna in the wetland. Notably, Deepar wetland happens to be a Ramsar site and the macro-invertebrate faunal diversity is enormous. The present paper describes five species of Bryozoa, namely the $19^{\text {th }}$ and $20^{\text {th }}$ century (Rao, 1992). However two species of

Hislopia lacustris moniliformis, Hyalinella punctata, Pactinatella gelatinosa, Plumatella emarginata and Fredericella sultana, and their ecological relationship.

\section{STUdY AREA}

Deepar wetland covering an area of $146.23 \mathrm{ha}$, is a perennial water body situated between $91^{0} 38^{\prime}-91^{\circ} 40^{\prime} \mathrm{E} \& 26^{\circ} 6^{\prime}-26^{0} 8^{\prime} \mathrm{N}$ near Guwahati, the capital city of Assam, India. The main wetland is subdivided into three major parts, the Barbeel, Kharbari and the Chanabeel. However, there are certain dendritic extensions at the northern part of the wetland. The wetland receives water from the river Brahmaputra through a canal, the khanajan which also acts as both inlet and outlet. Besides, it also regularly receives water from Basistha stream, which emerges from Meghalaya, India. The wetland has significant macrophytic diversity. The wetland was declared as Ramsar site in the year 2002 (vide Ramsar site no 1207, on 18 August 2002). The Innumerable migratory birds seasonally visit the remote extension of the wetland in its eastern part, while the main part is a disturbed fishing zone. The occurring area of Ectoproctan species in the wetland is demonstrated in Figure 1.

\section{Materials And Methods}

Monthly survey of the wetland are being conducted from 2004 until date to investigate the macro-invertebrate fauna associated with the diverse stand of macrophytes. The sample collection of bryozoan species along with other macro-invertebrates (not included here) was performed from time to time. The microhabitat structure of bryozoans on the surface of vegetation and on twigs are identified and marked. Collection of living sample was made by hand picking and by a special device for scrapping (when necessary). The living specimens were allowed to stand in the same wetland water in glass beakers. Live samples were observed and studied on the computer. The specimens were preserved in $4 \%$ formaldehyde solution after narcotizing with either $0.4 \% \mathrm{MgSO}_{4}$ aqueous solution or in menthol. Species identification was made following Edmondson (1959), Pennak (1953) and Rao (1992). The chemical parameters of water was analysed at the State Public Health Laboratory, Government of Assam and the physical parameters were observed in the study area (Table 1).

\section{SySTEMATIC ENUMERATION}

The systematic enumeration of the species included in this paper has been prepared based on the classification put forward by Annandale (1911).

\footnotetext{
${ }^{\mathrm{w}}$ See images in the web supplement at www.zoosprint.org
}

(C) Zoo Outreach Organisation; www.zoosprint.org Manuscript 1321; Received 25 January 2005; Revised received 21 July 2005; Finally accepted 29 October 2005: Date of publication 21 December 2005 January 2006 | ISSN 0973-2535 (Print edition); 0973-2551 (Online edition) 


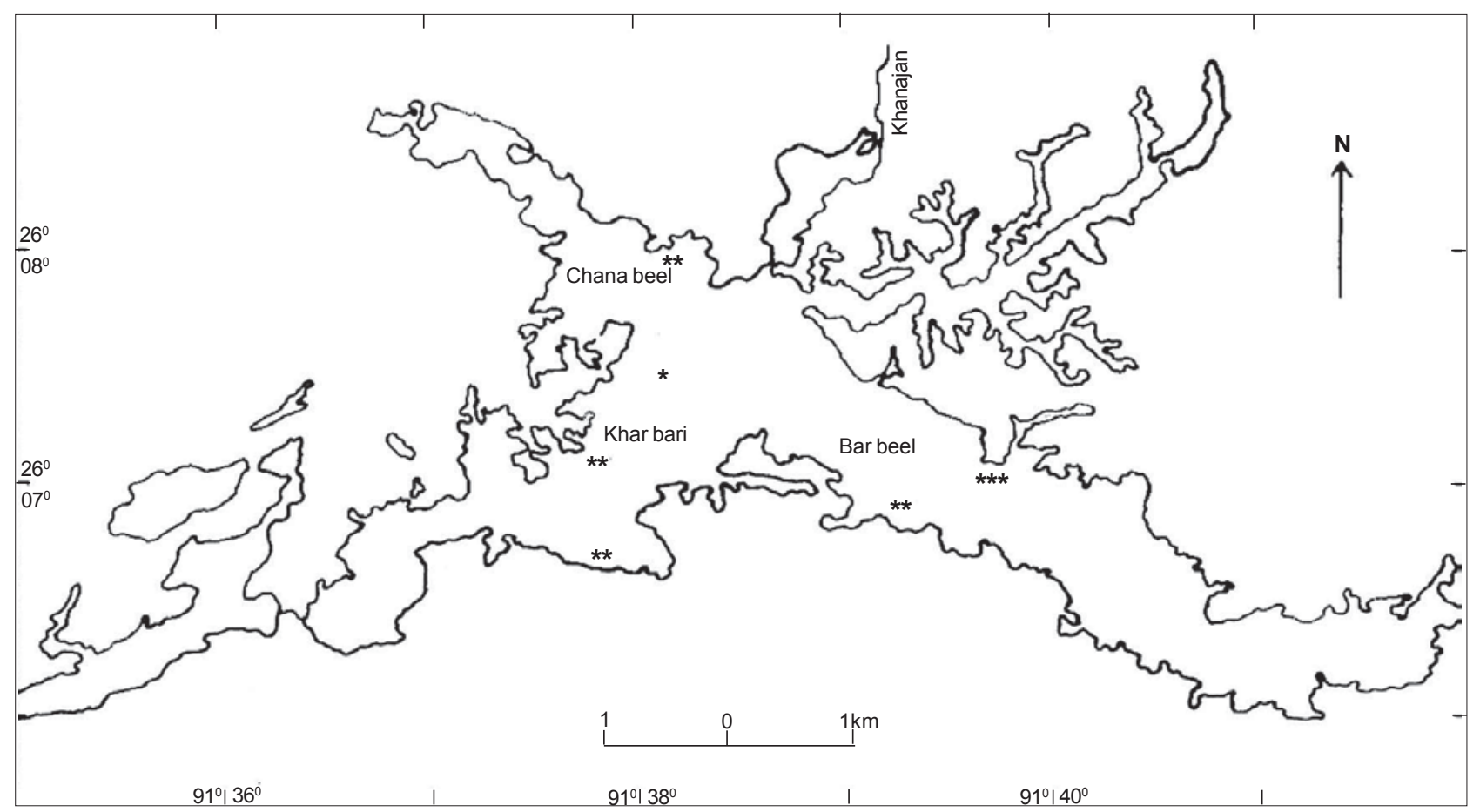

Figure 1. Map of Deepar wetland showing the zones of ectoproctan species occurrence. * Hislopia lacustris moniliformes, Plumatella emarginata, Hyalinella punctata; ${ }^{* *}$ - Pactinatella gelatinosa; ${ }^{* *}$ - Fredericella sultana

Class Ectoprocta

Order Gymnolaemata

Suborder Ctenostomata

Family Hislopiidae

\section{(a) Hislopia lacustris moniliformis (Annandale)}

The occurrence of Hislopia lacustris moniliformis in freshwater habitat of Indian sub continent was first described by Annandale in (1906). They are sessile animals, found over a wide variety of substrates. The zooids form beaded like colony encrustations on the host plant. Individuals never grow over on one another. Tentacular crown is circular. Number of tentacles vary from 14-16. Soft body part is easily visible through the chitinous zooecium (Images $^{\mathrm{W}} 1 \& 2$ ).

\section{Order Phylactolaemata \\ Family Plumatellidae \\ Subfamily Plumatellinae}

\section{(b) Plumatella emarginata (Allman)}

Plumatella emarginata is one of the common Ectoproctan animals having cosmopolitan occurrence. The zooecium in this species is dark brown in colour, with a lighter tip. Ectocyst is stiff and prominently keeled on the dorsal surface. The lophophore is horseshoe-shaped and it bears 37-40 tentacles. The floatoblast is oval, with a smooth capsular surface. The sessoblast are oval in appearance and the float covers more on one side than the other (Image $^{\mathrm{W}} 3 \& 4$ ).

\section{(c) Hyalinella punctata (Hancock)}

Hyalinella punctata provides a baggy transparent ectocyst. The ectocyst is transcluscent and endocyst is soft and fairly transparent.
The colony is faintly raddish-yellow in colour. Lophophore is horseshoe-shaped and it bears 50-55 tentacles. This animal bears numerous oval sessoblasts inside its zoocium (Image $5^{\mathrm{W}}$ ).

\section{Subfamily Lophopinae}

\section{(d) Pactinatella gelatinosa (Oka)}

In this species, the zoooids are embedded in a gelatinous mass. The zooecial tubes are radially arranged within the colony. The shape of the colony is roughly oval. Middle part of the colony does not possess any zooid. They are often observed undulating on the supporting host plants. The tentacular crown is horseshoeshaped and it bears 68 to 80 tentacles. The hoatoblast is large, rounded and the margin carries numerous spines $\left(\operatorname{Images}^{\mathrm{W}} 6\right.$ \& 7).

\section{Family Fredericellidae}

\section{(e) Fredericella sultana (Blumenbach)}

The species was found in little quantities on a fragmented floating stem of Hydrilla plant during the survey. The zooaria appear whitish with elongated dichotomous branching. Zooecium has greater diameter at the anterior end than the posterior. The tentacular crown is circular and it bears $24-26$ tentacles (Image $8^{\mathrm{w}}$ ).

\section{Microhabitat relationship of the species}

All the five observed species are sessile and periphytic in habitat. Hislopia lacustris moniliformis (Annandale) was observed on the lower base of Polygonum hydropiper as well as epizootic on the shell of Bellamya bengalensis. However, Hyalinella punctata and Plumatella emarginata were observed on the lower base of Polygonum hydropiper and Ipomea aquatica. These three species were abundant in Kharbari area of Deepar wetland. Pactinatella 
Table 1. Water quality of Deepar wetland studied during 2004-2005

\begin{tabular}{|c|c|c|c|c|}
\hline Parameters & Min & Max & Average & SD \\
\hline Appearance & & & Turbid & \\
\hline Temparature ${ }^{\circ} \mathrm{C}$ & 27.5 & 32.3 & 29.5 & 3.2 \\
\hline $\mathrm{pH}$ & 6.7 & 6.9 & 6.8 & 0.09 \\
\hline $\mathrm{DO}(\mathrm{mg} / \mathrm{l})$ & 5.9 & 6.9 & 6.3 & 0.35 \\
\hline B.O.D. (mg/l) & 2.3 & 12.4 & 7.35 & 5.05 \\
\hline Carbon-di-oxide as $\mathrm{CO}_{2} \mathrm{mg} / \mathrm{l}$ & 13.2 & 16 & 11.4 & 4.71 \\
\hline Total Suspended Solids (mg/l) & 45 & 55 & 52.5 & 2.75 \\
\hline Total hardness as $\mathrm{CaCO}_{3}(\mathrm{mg} / \mathrm{l})$ & 32 & 44 & 37 & 5.06 \\
\hline M. Alkalinity as $\mathrm{CaCO}_{3}(\mathrm{mg} / \mathrm{l})$ & 18 & 42 & 33.5 & 10.87 \\
\hline Calcium as $\mathrm{CaCO}_{3}(\mathrm{mg} / \mathrm{l})$ & 10 & 30 & 12.4 & 2.60 \\
\hline Magnesium as $\mathrm{Mg}(\mathrm{mg} / \mathrm{l})$ & 2.88 & 5.28 & 3.9 & 0.87 \\
\hline Chloride as $\mathrm{Cl}(\mathrm{mg} / \mathrm{l})$ & 8 & 10 & 8.25 & 1.25 \\
\hline Fluoride as $\mathrm{F}(\mathrm{mg} / \mathrm{l})$ & 0.03 & 0.035 & 0.03 & 0.00 \\
\hline Amonical Nitrogen as $\mathrm{NH}_{3}(\mathrm{mg} / \mathrm{l})$ & 0.02 & 0.4 & 0.3 & 0.06 \\
\hline Nitrite Nitrogen as $\mathrm{N}$ & & & Trace & \\
\hline Nitrate Nitrogen as $\mathrm{N}$ & Nil & 1.4 & 1 & 0.66 \\
\hline Sulphate as $\mathrm{SO}_{4}(\mathrm{mg} / \mathrm{l})$ & 3 & 42 & 20.8 & 15.97 \\
\hline Phosphate as $\mathrm{P}(\mathrm{mg} / \mathrm{l})$ & 0.2 & 0.3 & 0.24 & 0.04 \\
\hline Dissolved Organic Matters (mg/l) & 10 & 16 & 14 & 0.82 \\
\hline Conductance (micro mho/cm) & 80 & 130 & 112.3 & 7.59 \\
\hline
\end{tabular}

another, for which seasonal flood can be considered as one of the important factors.

All the species may have their community association as observed by Rao (1992). However, the occurrence of Pectinatella gelatinosa in a wide variety of host plant indicates its dominance over all the other species in Deepar wetland. The water quality of Deepar wetland has the tropical relations. As, most of the bryozoans are common in tropical habitat, there is a possibility of occurrence of some more species in this wetland for which further investigation is required.

\section{REFERENCES}

Annandale, N. (1906). Notes on the fresh water fauna of India. No. II. The affinities of Hislopia. Journal of Asiatic Society of Bengal (new series) ii, 59(2): Annandale, N. (1911). Freshwater Sponges, Hydroids and Polyzoa, pp.62205. Fauna of British India. Taylor and Francis, London.

Benerjee, S.M. and M.P. Motwani (1960). Observations on pollution of the suvaon stream by the effluents of Sugar Factory at Balrampur (UP). Indian Journal of Fish 7(1): 107-128.

Table 2. Comparative account of Ectoproctan fauna of Deepar wetland

\begin{tabular}{|c|c|c|c|c|c|c|}
\hline S. No & Name of the Species & Shape of lophophore & $\begin{array}{l}\text { No. of } \\
\text { tentacles }\end{array}$ & Name of the primary host plant & $\begin{array}{l}\text { Season of } \\
\text { occurrence }\end{array}$ & Statoblast \\
\hline 1 & Hislopia lacustris moniliformis & Circular & $14-16$ & P. hydropiper and B. bengalensis & Mar-Apr & Not present \\
\hline 2 & Hyalinella punctata & Horse shoe shaped & $50-55$ & $P$. hydropiper and I. aquatica & Feb- May & Present \\
\hline 3 & Pectinatella gelatinosa & Horse shoe shaped & $68-80$ & $\begin{array}{l}\text { H. verticillata, V. spiralis, E. cressipes, } \\
\text { P. hydropiper, and C. demersum }\end{array}$ & Oct-May & Present \\
\hline 4 & Plumatella emarginata & Horse shoe shaped & $37-40$ & P.hydropiper and I. aquatica & Feb- Jun & Present \\
\hline 5 & Fredericella sultana & Circular & $24-26$ & $H$. verticillata & April & Present \\
\hline
\end{tabular}

gelatinosa grew on a wide variety of plants like Hydrilla verticillata, Vallisneria spiralis, Eichhornia crassipes, Polygonum hydropiper, and Ceratophyllum demersum. However, their density was found more in $H$. verticillata. This species was evenly distributed throughout the wetland. However, only a small sample of Fredericella sultana on a fragmented stem of $H$. verticillata was collected from Barbeel area of Deepar wetland in April 2004. Therefore, the exact habitat and ecology of this species is yet to be studied. A comparative account of the studied species is given in Table 2.

\section{Discussion}

The bryozoan diversity is presumably rich in the sub-tropical freshwater environment of Assam, but due to lack of literature and ignorance, its frequency of occurrence is not reported from this entire region. Being an exclusively freshwater zone, Assam and its northern, southern and eastern extensions may hold rich diversity of freshwater bryozoan species in the wetlands besides many other habitats, and may coincide with many reports pouring from several countries (Pennak, 1953; Edmondson, 1959; Wood \& Wood 1998) since the freshwater bryozoans are cosmopolitan in distribution. The present report of five bryozoan species from a single wetland is in support of the rich diversity of the group. The wetland is famous as a bird sanctuary and composite species population of cosmopolitan freshwater Bryozoa may be propagated by migratory species of birds. Moreover, annual flushing of water of the wetland may transport the statoblasts from one place to
Blumenbach, J.T. (1780). Handbuch der Naturgeshiente. Gottingen.

Bushnell, J.H. and K.S. Rao (1974). Dormant and quiescent stages and structure among the Ectoprocta; Physical and chemical factors affecting viability and germination of statoblast. Transactions of the American Microscopic Society 93(4): 524-543.

Bushnell, J.H. and K.S. Rao (1979). Freshwater Bryozoa Microarchitecture of statoblast and some aufwuch animal associated, pp. 55-70. In: Larwood and Abbot (Eds.) Advances in Bryozoology.

Choubey, U. (1984). Biological studies on some freshwater Bryozoa of Ujjain area. M.Phil Thesis. Vikram University, Ujjain (unpublished).

Edmondson, W.T. (ed) (1959). pp. 495-507. In: Freshwater Biology $2^{\text {nd }}$ edition. Wiley, New York,

Goswami, M.M. (1985). Limnological investigations of a tectonic lake of Assam, India and their bearing on fish production. Ph.D. Thesis, Gauhati University, Guwahati (unpublished).

Pennak, R.W. (1953). Freshwater Invertebrates of the United states. Ronald Press Co. New York,

Rao, K.S. and N. Ghosh (1962). On the extension of the geographical distribution of Hislopia lacustris sub sp. moniliformis Annandale (Ectoprocta: Gymnolaemata) along with a note on its morphological peculiarities. Journal of the University of Saugar II(B): 11-13.

Rao, K.S. (1976). Studies on freshwater Bryozoa VI. The Bryozoa of Rajasthan. Records of Zoological Survey of India (Fauna of Rajasthan volume) 15(69): 329-345.

Rao, K.S. (1992). Fresh Water Ecology (Bryozoa). Anmol Publication. Wood, T.S. and L.J. Wood (1998). Freshwater bryozoans of New Zealand: a preliminary survey. New Zealand Journal of Marine \& Freshwater Research 32: 639-648.

Wood, T.S. (2004). First Report on Hislopia Larva, Thailand Freshwater Bryozoan Website, BPK Project Progress.

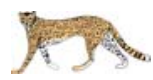

